\title{
Management and Safety Practices in the Pyrotechnics Industry: The Province of Bulacan Experience
}

\author{
Felicidad A. Dy Kam, DBA \\ Assistant Professor, Department of Management and Human Resources, College of Financial Sciences, \\ AMA International University-Bahrain, Salmabad, Kingdom of Bahrain
}

\begin{abstract}
This study determined the management and safety practices of pyrotechnics manufacturers and dealers in the province of Bulacan towards the effective management and implementation of safety policies in the pyrotechnics industry. Specifically, it investigated the following sub-problems: 1. How can the profile of the respondent manufacturers and dealers of pyrotechnics can be described in terms of the following: Sources of technical and managerial skills, Sources of funding, Building ownership, Monthly rentals, Manufacturing period, Distribution period, Profits earned; 2. What are the management practices of the respondent manufacturers and dealers in terms of the following areas: Production and Dealership; 3. What common problems were encountered by the two groups of respondents and which of them has the greatest impact? 4.To what extent are the provisions of RA 7183 implemented by the respondents when grouped as follows: Manufacturer and Safety Policy Authority respondents, Dealer and Safety Policy Authority respondents, Dealer and Manufacturer respondents ; 5.Is there a significant difference on the extent of implementation of safety measures provided by the RA7193 when the respondents are grouped as follows: Dealer and Safety Policy Authority respondents and Dealer and Manufacturer respondents. This study employed the descriptive method of research, which investigated the management and safety practices of fireworks manufacturers and dealers and the safety policy authorities of Bocaue and Sta. Maria, Bulacan. The respondents of the study were the pyrotechnics manufacturers, the dealers and the DOH local employees of Bocaue and Sta. Maria Bulacan. The researcher used the survey questionnaire in order to gather data. The frequency distribution, percentage distribution, weighted mean and two mean t-test were used by the researcher for the statistical tool of the study. 1. Most of the manufacturers and dealers obtained their pyrotechnics materials and products on cash basis. 2.Invasion of cheap imported products was the greatest problem in the pyrotechnics business. 3.There were differences in the extent of implementation of the pyrotechnics manufacturers and dealers and safety policy authorities in relation to safety measures. 4.There was a significant difference in the extent of implementation of pyrotechnics dealers and safety policy authorities as to the extent of following the requirements for safety.
\end{abstract}

Keywords: Pyrotechnics, Safety Policy, Dealers, Manufacturers, Safety Policy Authorities

\section{INTRODUCTION}

The word pyrotechnics refers to the art, craft, and science of fireworks. It is said that the birthplace of fireworks is China. Legend has it that a Chinese cook accidentally mixed three common ingredients: potassium nitrate, sulfur and charcoal, and which he lighted, a mass of colorful flames burst forth. The cook also noticed that if the mixture was burned when enclosed in the hollow of a bamboo stalk, there was a tremendous explosion. The first application of this technology was for entertainment. Pyrotechnics which is sometimes called fireworks and firecrackers, are products formed from the mixtures of gunpowder and other elements which are shaped, or pressed together to develop the firework products desired. In the Philippines, the beginnings of the pyrotechnics industry was a non-formal business owned by families with the purpose of providing fun and entertainment in special occasions such as fiestas, Christmas, New Year's Eve, weddings and baptism to create a joyful and festive environment. The continuing demand for the pyrotechnic products over the years has motivated the family owners of the business to produce more and supply the increasing demand of the consumers. It has attracted more business

oriented families to venture in the business. Manufacturers and dealers grew rapidly due to the high profits generated by the industry. Although it is hard to quantify revenues from pyrotechnics because of the proliferation of underground establishments and smuggled goods, it is noted that the industry is worth about P350400 million. The industry provides employment and enterprise development opportunities for some 100,000 locals [1]. However, this has also made the town susceptible to large fires every New Year. Despite the efforts of the local and provincial government of the province of Bulacan to implement the safety policies in the pyrotechnics industry, it observed that many stakeholders of the industry still resort to procedures and practices that are not healthy to its growth. According to the report, many dealers in Bocaue, Bulacan, have stocks of imported products allegedly made by local fireworks manufacturers and these inferior products which are believed to be produced by the manufacturers who do not totally follow 
the safety measures, are the source of fireworks accidents that instigated injuries and sometimes death to the New Year revelers.

\section{RESEARCH METHODOLOGY}

This study employed the descriptive method of research which investigated the management and safety practices of fireworks manufacturers and dealers and the safety practices authorities of Bocaue and Sta. Maria, Bulacan. The total number of the pyrotechnics dealers of Bocaue, Bulacan is 139 and there are 4 dealers in Sta. Maria, Bulacan with a cumulative sum of 143 of which, 15 were not included in the choice of respondents because they were utilized as persons who pretested the survey questionnaire. The manufacturers from Bocaue are 22 and there are 27 from Sta. Maria, both small and big manufacturing enterprises which is equivalent to 49 of which 3 of them were also utilized as the persons who pretested the survey questionnaire. The safety policy authorities which are composed of the Bocaue and Sta. Maria Philippine National Police members, the Bureau of fire Protection personnel and the employees of the local Department of Health are 43. The researcher used extensively the survey questionnaire. The following statistical tools were used in the study: Frequency distribution, Percentage distribution, Weighted mean and T-test.

\section{RESULTS AND DISCUSSION}

A. Profile of the Pyrotechnics Manufacturers and Dealers

1. Profile of Respondents as to the Sources of Technical and Managerial Skills in Business Operation. Table 1 disclosed the profile of respondents as to the sources of technical and managerial skills in business operation. Thirty-one or $75.61 \%$ of the manufacturers learned their technical and managerial skills from experience learned from parents. Fifty-two or $53.61 \%$ of the pyrotechnics dealers learned their technical and managerial skills from self-study and observation. This means that most of the manufacturers and dealers under study did not undergo any formal training to learn the basics of the business.

2. Profile of Respondents as to Sources of Funds/Initial Capital. Table 2 showed the sources of funds/initial capital of the respondent manufacturers and dealers. Thirty one or $75.61 \%$ of the manufacturers' capital came from their own savings. There are 66 or $68.04 \%$ dealers who revealed that their initial funds came from their own savings. The implication of these findings is that most of the pyrotechnics manufacturers and dealers are all sole proprietors and they are the owners of the business.

3. Profile of Respondents as to Building Ownership. Table 3 illustrated the profile of respondents as building ownership of the pyrotechnics manufacturers and dealers. Thirty or $73.17 \%$ of th manufacturer revealed that the building is rented. On the part of the dealer, sixty eight or $70.10 \%$ said that it is rented. Majority of the manufacturers and dealers are renting the land and the building of the business location. The data stated that the respondents are not regular occupants of the place and was complemented by the temporary use of permit that the respondents had to secure before the business starts.

4. Profile of Respondents as to Monthly Payment for Building for Business Purposes. Table 4 demonstrated the profile of the respondents as to monthly payment of pyrotechnics manufacturers and dealers for the building and location for business purposes. It also showed that several of the manufacturers and dealers will not rent a place which will have a higher rent due to the fact that the capital investment of the majority of the respondent manufacturers and dealers are coming from their own savings.

5. Beginning Month of Manufacturing and Distribution of Pyrotechnics Product. Table 5 revealed the profile of the respondents as to the beginning month of manufacturing and distribution of pyrotechnics products. Twelve or $29.27 \%$ is the highest number of the manufacturers who affirmed that the season for manufacturing pyrotechnics products is in the month of September followed by the month of January while thirty-one or $31.96 \%$ is the highest number of the dealers who confirmed that the month of October is the month to start distributing/selling the pyrotechnic products. The manufacturers and dealers do not open the business in lean months but engaged in other businesses such as selling fruits and other products in season as it is seen and observed in the location.

6. Profile of Respondents as to Peak Season Months for Manufacturing and Selling/ Distributing Pyrotechnics Products. Table 6 disclosed the profile of the respondents as to the peak season months for manufacturing and distribution of pyrotechnics products. Forty or $97.56 \%$ of the respondent manufacturers revealed that the month of December is the peak season for manufacturing and selling pyrotechnics products For the dealers, sixty seven or $69.07 \%$ said that December is the peak season for selling the products. The data demonstrated that the manufacturers and dealers are supplying the needs of the buyers who purchase the pyrotechnic products in December in preparation for the New Year's celebration.

7. Profit Earned by Pyrotechnics Manufacturers and Dealers. Table 7 explained the profile of the respondents as to profit earned by pyrotechnics manufacturers and dealers. The figures in the table revealed that not one of the respondents have incurred losses in the operation which make the pyrotechnics industry a very valuable source of income.

B. Management Practices of the Respondent Pyrotechnics Manufacturers and Dealers in terms of:

1. Management Practices on Production as to the Method of Obtaining Pyrotechnic Materials from Suppliers. Table 8 showed the management practices of the pyrotechnics manufacturers and dealers in terms of production as to obtaining pyrotechnics materials from suppliers. Thirtyeight or $92.68 \%$ of the respondent manufacturers showed 
that the products are obtained through cash basis. Seventy three or $75.26 \%$ of the dealers said that they acquire the materials from suppliers on cash basis. The manufacturers and dealers paid cash to obtain the supplies due to the fact that the suppliers have to save the money for initial capital purposes for the next business operation.

2. Management Practices on Dealership as to Terms of Sales and Deliveries. Table 9 showed the management practices of pyrotechnics manufacturers and dealers on dealership as to terms of sales and deliveries. Thirty eight or $92.68 \%$ of the manufacturers disclosed that the pyrotechnics products are sold in cash basis. Most of the respondent manufacturers and dealers showed that the products are obtained through cash basis. The buyers of the products paid cash due to the fact that the manufacturers and dealers have to save the money for capital purposes for the next business operation. It can be surmised that majority of the sources of the initial capital of the respondents are coming from their own savings.

3.Management Practices on Dealership in Terms of Sales Increase. Table 10 revealed the management practices of pyrotechnic manufacturers and dealers on dealership as to sales increase. Thirty nine or $95.12 \%$ disclosed that sales increases is due to promotion by word of mouth. The primary process to increase the sales is the promotion by word of mouth as disclosed by 39 manufacturers and 58 of the dealers. These processes of sales increase is the practice of the manufacturers and dealers since Bulacan is the pyrotechnic capital of the Philippines and it is known in the entire country.

C. Common Problems Encountered by the Respondent Manufacturers and Dealers.

1. Problems with Greatest Impact in the Pyrotechnic Business. Table 11 demonstrated the problems with greatest effect in the pyrotechnics business. Twenty nine or $70.73 \%$ of the manufacturers said that production cost is the problem with greatest effect in the pyrotechnics business. Thirty one or $75.61 \%$ stated that the invasion of cheap imported products is the greatest problem they are facing. Forty eight of $49.48 \%$ of the pyrotechnics dealers revealed that production cost affect their business.

2. Common Problems of Pyrotechnic Manufacturers and Dealers in the Area of Marketing (Combined Result). Table 12 illustrated the common problems of pyrotechnic manufacturers and dealers in the area of marketing. Ninety Five or $68.84 \%$ of the respondents showed that strong competition is one of the marketing problems and 28 said that the seasonality of the products is a marketing problem for the product. Majority of the manufacturers and dealers demonstrated that strong competition is the primary problem in marketing the product and followed by cost increases on supplies or price increases in the supplies of raw materials and the price increases on finish pyrotechnics products.

3. Common Problems of Pyrotechnics Manufacturers and Dealers in the Area of Finance (Combined Result). Table
13 demonstrated the common problems encountered by pyrotechnics manufacturers and dealers in the area of finance. Ninety seven or $70.29 \%$ revealed that short of cash for the initial capital is their financial problem and 89 or $64.49 \%$ stated that short of cash for operating expenses is also a financial problem of the respondent. These findings implied that the pyrotechnics manufacturers and dealers only have few accesses to credit and that the majority of the manufacturers and dealers have to save the profit earned during the peak season in order to start the business for the next business operation.

$D$.Extent of Implementation of RA 7183 by the Two Groups of Respondent.

1. Extent of Implementation of $R A 7183$ by the Manufacturer and Safety Policy Authority Respondents in Relation to Licensing. Table 14 explained the extent of implementation of RA 7183 by the manufacturers and safety policy authority respondents in relation to licensing. Among the requirements for licensing for the manufacturers, all the respondents had illustrated that all the requirements for licensing have been followed by the manufacturers and safety policy authorities. This reveals that the extent of implementation of RA 7183 by the manufacturer and dealer respondents in relation to licensing has a different degree on the part of the two groups of respondents as it is shown in the subsequent tables

2. Extent of Implementation of RA 7183 by the Manufacturer and Safety Policy Authority Respondents in Relation to Temporary Use Permit. Table 15 revealed the extent of implementation of RA 7183 by the manufacturer and safety policy authority respondents in relation to temporary use permit. The manufacturer and safety policy authority demonstrated that they always follow the rules in terms of the use of temporary permit.

3. Extent of Implementation of RA 7183 by the Manufacturer and Safety Policy Authority Respondents in Relation to the Location of the Manufacturing Complex. Table 16 explained the extent of implementation of RA 7183 by the manufacturer and safety policy respondents in relation to the location of the manufacturing complex. The manufacturers revealed that the manufacturing complex has adequate ventilation, has no concrete floor, is leak proof, and has a fire extinguisher. This safety guideline acquired a mean rating of 3.97 with a qualitative meaning of "always". For the safety policy authorities, most of the items have a mean rating of 3.31 and 3.45 , respectively, with a verbal interpretation of "always". However, item 3 and 4 obtained a mean rating of 3.12 and 3.00, respectively, with a qualitative meaning of "more often".

4. Extent of Implementation of $R A 7183$ by the Manufacturer and Safety Policy Authority Respondents in Relation to the Safety Guidelines During the Processing of Pyrotechnics Products. Table 17 demonstrated the extent of implementation of RA 7183 by manufacturer and safety policy respondents in relation to the safety guidelines during the processing of pyrotechnic products. "The 
manufacturers inform the workers that the chemicals to be used for processing shall be limited to the smallest quantity necessary for safe, economical and efficient operations" and "The workers keep the chemicals closed and covered in a containers at all times except during processing" got a mean rating of 4.0 each with a qualitative meaning of "always". The manufacturers and the safety policy authorities have a different degree of perception in the extent implementation of in relation to safety guidelines during the processing of the pyrotechnics products.

\section{Extent of Implementation of RA 7183 by the Dealer and} Safety Policy Authority Respondents in Relation to Safety Measures to Prevent Fire and Damage to Properties, Injuries and Casualty. Table 18 illustrated the extent of implementation of RA 7183 by the dealer and safety policy authority respondents in relation to safety measures to prevent fire and damage to properties, injuries and casualty. Among the safety measures to prevent fire and damage to property, injuries and casualty on the part of the manufacturers, "Putting of the fire extinguisher inside the store is required", got the highest mean rating of 4.0 with a qualitative meaning of "always". The dealers said that they "always" prevent individuals to smoke within 10 meter radius perimeter of the fireworks. These results are complemented by the reports of the Bocaue Fire Protection personnel about some of the deficiencies of the manufacturers and dealers with regards to the necessary safety equipments that must be displayed in the manufacturing sites and in the stores.

6. Extent of Implementation of RA 7183 by the Manufacturer and Dealer Respondents in Relation to Licensing. Table 19 presented the extent of implementation of RA 7183 by the manufacturer and dealer respondents in relation to licensing. The two groups of respondents showed that they always implement the RA 7183 in relation to licensing. On the part of the manufacturers, the item with the highest mean rating was item 3 (Secure business permit duly issued by the municipal mayor/treasurer of the place) with a mean rating of 4.00. The highest mean given by the dealer respondents is for item 5 (The detail and location plan of the warehouse is duly noted by the barangay chairman, and the chief of the local fire station) with a mean rating of 3.90. This means that the two groups of respondents had different extent of implementation of RA 7183 in relation to licensing as shown by the different mean ratings presented. On the average, the manufacturer and dealer respondents revealed that they "always" implement the RA 183 in relation to licensing their business but different in the weighted means.

7. Extent of Implementation of RA 7183 by the Manufacturer and Dealer Respondents in Relation to Temporary Use Permit Table 20 revealed the extent of implementation of RA 7183 by the manufacturer and dealer respondents in relation to temporary use permit. The two groups of respondents showed that they always implement the RA 7183 in relation to licensing. However, they had different mean ratings for each item. On the part of respondent dealer, the item with the highest mean rating is 4 for item 1 (Secure clearance from the Barangay Council for authority to manufacture fireworks). On the part of the dealers the highest mean rating given was 3.86 for item 1 (Secure clearance from the Barangay Council for authority to manufacture fireworks. This means that the two groups of respondents had different extent of implementation of RA 7183 in relation to temporary use permit as shown by the different mean ratings presented.

E. Significant Difference in the Extent of Implementation of Safety Measures by the Two Groups of Respondents.

1. Significant Difference in the Extent of Implementation by Dealer and Safety Policy Authority Respondents in Relation to Licensing. Table 21 showed an independent two sample t-test was conducted at 5 percent level of significance. For the licensing, the computed t-test had a value of 6.060 at 132 degrees of freedom and a corresponding p-value of 0.00 which was less than the 5 percent level of significance, the null hypothesis of no significant difference in the extent of implementation by dealer and safety policy respondents in relation to licensing was rejected. Therefore, the perceptions of the dealers and of the safety policy authorities as to the extent of implementation of the requirements for licensing are significantly different at the $5 \%$ level of significance.

\section{Significant Difference in the Extent of Implementation} by the Dealer and Safety Policy Respondents in Relation to Temporary Use Permit. Table 22 showed the significant difference in the extent of implementation by the dealer and safety policy respondents in relation to temporary use permit. An independent sample t-test was conducted at 5\% level of significance to know the significant difference in the extent of implementation by the dealer and safety policy respondents in relation to temporary use permit. The table also revealed the computed t-value of 4.754 with a corresponding p-value of 0 and with a level of significance of .05 and a degree of freedom of 133, the null hypothesis of no significant difference on the perception of pyrotechnics dealers and safety policy officer as to the extent of implementation by the dealer and safety policy respondents in relation to temporary use permit was rejected.

Therefore, the assessments of the dealers and of the safety policy authorities as to the extent of implementation by the dealer and safety policy respondents in relation to temporary use permit were significantly different at the $5 \%$ level of significance.

- Significant Difference Extent of Implementation by the Dealer and Safety Policy Authority Respondents in Relation to Safety Practices to Prevent Fire and Damage to Properties, Injuries and Casualty. Table 23 revealed the significant difference in the extent of implementation by the dealer and safety policy respondents in relation to safety practices to prevent fire and damage to properties, injuries and casualty. With a level of significance of .05 
and a degree of freedom of 135 , the computed t-value was 3.266 and with a corresponding p-value of 0 , it means that the null hypothesis of no significant difference in the extent of implementation by the dealer and safety policy respondents in relation to safety practices to prevent fire and damage to properties, injuries and casualty was rejected. Therefore, the extent of implementation by the dealer and safety policy respondents in relation to safety practices to prevent fire and damage to properties, injuries and casualty are significantly different at the $5 \%$ level of significance.

F. Significant Difference in the Extent of Implementation of Safety Measures by the Two Groups of Respondents.

1. Significant Difference in the Extent of Implementation by the Manufacturer and Dealer Respondents in Relation to Licensing. Table 24 demonstrated the significant difference in the extent of implementation by the manufacturer and dealer respondents in relation to licensing. To determine the significant difference in the extent of implementation by the manufacturer and dealer respondents in relation licensing, an individual two sample t-test was conducted. The t- statistics obtained a value of 1.764 at 130 degrees of freedom and a corresponding pvalue of 0.80 which is greater than the 5 percent level of significance, the null hypothesis of no significant difference in the extent of implementation by the manufacturer and dealer respondents in relation licensing was not rejected. Therefore, there is no significant difference in the in the extent of implementation by the manufacturer and dealer respondents in relation to licensing.

\section{Significant Difference in the Extent of Implementation} by the Manufacturer and Dealer Respondents in Relation to Temporary Use Permit. Table 25 showed the significant difference in the extent of implementation by the manufacturer and dealer respondents in relation to temporary use permit. An independent sample t-test was conducted at $5 \%$ level of significance to know the significant difference in the extent of implementation by the manufacturer and dealer respondents in relation to temporary use of permit. Table 2 also revealed the computed t-value of -0.558 with a corresponding $\mathrm{p}$-value of 0.57 and with a level of significance of .05 and a degree of freedom of 131, the null hypothesis of no significant difference in the extent of implementation by the manufacturer and dealer respondents in relation to temporary use permit was not rejected. Therefore, there was no significant difference in the extent of implementation by the manufacturer and dealer respondents in relation to temporary use permit.

\section{The following are the findings of the study:}

1. Thirty eight or $92.68 \%$ of the manufacturers obtained their pyrotechnics materials from suppliers to be used for producing pyrotechnics products on cash basis.
2. In terms of problems in production, the manufacturers and dealers stated that invasion of cheap imported products is the problem with greatest effect in the pyrotechnics business.

3. There were differences in the extent of implementation of the pyrotechnics manufacturers and dealers and safety policy authorities in relation to safety measures. There was a difference in the extent of implementation of the manufacturers and dealers in relation to licensing as well as on the temporary use permit.

4. There was a significant difference in the extent of implementation of pyrotechnics dealers and safety policy authorities as to the extent of following the requirements for licensing. There was a significant difference in the extent of implementation of pyrotechnics dealers and safety policy authorities as to the extent of implementing the requirements for temporary use permit. There was a significant difference in the extent of implementation of pyrotechnics dealers and safety policy authorities as to the extent of following the safety practices to prevent fire and damage properties, injuries and casualty. There was no significant difference in the perception of pyrotechnics manufacturers and dealers as to the extent of following the requirements for licensing. There was no significant difference in the perception of pyrotechnics manufacturers and dealers as to the extent of following the requirements for temporary use permit.

\section{V CONCLUSION}

Based on the findings of the study, the following conclusions were derived: The manufacturers and dealers of pyrotechnics obtained pyrotechnics materials from suppliers through cash basis. The terms of sales and deliveries of pyrotechnics products are through cash basis followed by credit. The primary process to increase the sales is the promotion by word of mouth. The second process to increase the sales is to give discount to the customers.

The primary problem which affected the business operation of the manufacturers and dealers is the invasion of cheap imported products and second is the production cost. To the pyrotechnics manufacturers and dealers strong competition is the primary problem in marketing their product as well as cost increases on raw materials and on finished pyrotechnics products. The extent of implementation of the pyrotechnics manufacturers and safety policy authorities in relation to licensing was the same in terms of verbal interpretation but different means. The extent of implementation of the pyrotechnics manufacturers and safety policy authorities as to the extent of implementing the temporary use permit in terms of verbal interpretation was different in other items but similar in other items. There were differences in the means of the two groups. There was a difference in the degree of assessment between the pyrotechnics dealers and the safety policy authorities in the extent of implementing the requirements of licensing. The two groups had similar responses in terms of verbal interpretation but different in 
the means. The pyrotechnics manufacturers, dealers and safety policy authorities had significant difference in the extent of implementation of safety measures in the pyrotechnic industry. There was a significant difference in the extent of implementation of the dealers and safety policy authorities as regards to licensing as well as in the implementation of safety practices to prevent fire and damage to properties, injuries and casualty but there is no significant difference in the extent of implementation of the manufacturers and dealers as regards to licensing and temporary use permit.

\section{ACKNOWLEDGMENT}

I would like to extend my gratitude to my respondent banking institutions, to my friends who introduced me to this publication journal and to International Advanced Research Journal in Science and Engineering and Technology for giving me the opportunity to publish this research study.

\section{REFERENCES}

[1] htpp://www.bulacan.gov.ph: Brief History of Pyrotechnics

[2] Cooper Dale F., S. Grey, G. Raymond and P. Walker. (2005). West[1] Sussex, England. John Wiley \& Son, Ltd., West Sussex, England.

[3] Deshmukh, L. M. (2006). Industrial Safety Management. New York. Tata McGraw Hill Publishing Company Limited.

[4] Go, Josiah. (2001). Marketing in the Philippine Setting.. QC, Philippines. Design Plus

[5] Tarlow, Peter E. (2002). Event Risk Management and Safety. New York. John Willey \& Son, Inc.

[6] Vaughan, E. J. Risk Management. New York. John Wiley \& Son, Inc.

[7] Young, F. C. and C. Pagoso. (2008). Principles of Marketing. Manila, Philippines. Rex Bookstore

[8] Alcantara, Antonio N. (2002) "The Marketing Practices of Convenient Stores in the Province of Bulacan: An Assessment"

[9] Narcida, Angelita N. (1984) "Management Practices of Domestic Construction Firms in Metro Manila"

[10] http://dspace.lib.cranfield.ac.uk/bitstream: Towards Unified Theory of Strategic Manufacturing (PDF)(2010)

[11] http://highered.mcgraw-hill.com: The Evolution of Management Theory(2011)

[12] http://pom.ir/wp-content/uploads/PDF: Theory of Constraints: A Theory for Operations Management

[13] http://www.laws.chanrobles.com/ph/ra/: Republic Act No. 7183 (2010)

[14] http://www.tmcnet.com: Pyrotechnics Industry in the Philippines (2010)

[15] http//www.wardsdealer.com: CRM Requires Return on Effort (2010) (7)

[16] http://www.en.wikipedia.org: Theory of Constraints (3) (2010) (2011)

[17] http://www.oppapers.com: Operations Management (2011)

[18] http://www.turnaround.org: Theory of Constraints (2011)

[19] http://www.scribd.com: Social Marketing Theory (2011)

[20] http://www.sara-stewart.com: The Domino Theory (2011)

[21] http://www.ehstoday.com: How Fireworks Work (2011)

[22] http://www.books.google.com.ph: Fireworks Ready to Boom (2010)

[23] http//www.answers.yahoo.com: Pyrotechnics Safety Guidelines(2011)

[24] http://www.schoolsite.edex.net.uk: Measures to Tackle Fireworks Misuse

[25] http://www.helpme.com: The Chemistry of Fireworks (2010)

[26] http://www.safety.lovetoknow.com: Fireworks Safety tips(2010)

[27] http;//www.images2.co.uk: Pyrotechnics Explosives (2010)

[28] http://www.createfireworksshw.com:Pyrotechnics on Hoe to Make fireworks

[29] http://www.ors.act.gov.au/ors/pdfs/Newsletter/ORS_E-News_pdf: $\quad A C T$ Fireworks License Holders Information (2010)

[30] http://www.fire.state.mn.us: Fireworks Guidelines Revise 2004 (2010)

[31] http://www.enotes.com: Fireworks (2010)

[32] http://www.skylinemedical center.com: Fireworks Safety: Avoiding Injury(2010)

[33] http://www.ky3.com: Missouri Fire Marshall Urges Caution with Fireworks(2010)

[34] http://www.maricopa.gov: Summer Safety

[35] http://positivenewsmedia.net: Bulacan Pyromakers Urged to Produce Safe, Good Quality Fireworks

[36] http://www.tucp.org.ph: How Fireworks Work

[37] http://www.mbcom.ph: Bulacan Fireworks Industry Alive Again

[38] http://www.oshcenter@oshc.dole.gov.ph: Assessing the Occupational Safety 
International Advanced Research Journal in Science, Engineering and Technology

Vol. 2, Issue 1, January 2015

Profile of Respondents as to the Sources of Technical and Managerial Skills in Business Operation

TABLE 1

Profile of Respondents as to the Sources of Technical Technical and Managerial Skills Sources of technical and Managerial Skills Manufacturer Dealer

Overall

Schooling

$\begin{array}{ll}\text { Frequency } & \text { Percentage } \\ 0 & 0 \\ 31 & 75.61 \\ 25 & 60.98 \\ 19 & 46.34 \\ 6 & 14.63 \\ 1 & 2.44\end{array}$

$\begin{array}{ll}\text { Frequency } & \text { Percentage } \\ 10 & 10.31 \\ & \\ 44 & 45.36 \\ 52 & 53.61 \\ 26 & 26.80 \\ 23 & 23.71 \\ & \\ & \\ & \end{array}$

$\begin{array}{ll}\text { Frequency } & \text { Percentage } \\ 10 & 7.25 \\ & \\ 75 & 54.35 \\ 77 & 55.80 \\ 45 & 32.61 \\ 29 & 21.01 \\ & \\ & \\ & \end{array}$

Seminars and trainings

TABLE 11

Profile of Respondents as to Sources of Funds/Initial Capital

Sources of Funds/Initial Capital Manufacturer Dealer

Overall

From own savings

From relatives and friends

From government banks

Loans from private banks

Loans from cooperatives

Loans from individual money lenders

$\begin{array}{ll}\text { Frequency } & \text { Percentage } \\ 31 & 75.61 \\ 9 & 21.95 \\ 0 & 00 \\ 3 & 7.32 \\ 21 & 51.22 \\ 8 & 19.51\end{array}$

$\begin{array}{ll}\text { Frequency } & \text { Percentage } \\ 66 & 68.04 \\ 24 & 24.74 \\ 5 & 5.15 \\ 14 & 14.43 \\ 35 & 36.08 \\ 15 & 15.46\end{array}$

$\begin{array}{ll}\text { Frequency } & \text { Percentage } \\ 97 & 70.29 \\ 33 & 23.91 \\ 5 & 3.62 \\ 17 & 12.32 \\ 56 & 40.58 \\ 23 & 16.67\end{array}$

TABLE 111

Profile of Respondents as to Building Ownership

Item

Building Ownership

Owned

53.62

Total

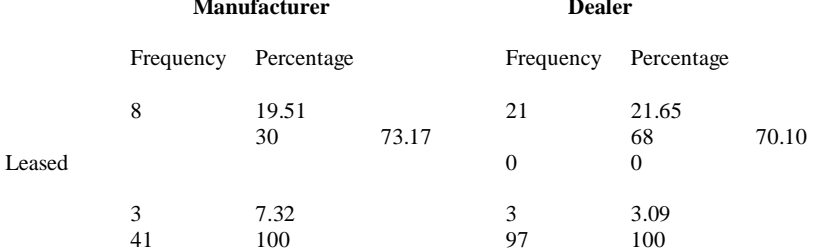

\begin{tabular}{ll}
\multicolumn{2}{c}{ Overall } \\
Frequency & Percentage \\
29 & 21.01 \\
& 98 \\
5 & 5.15 \\
6 & 4.35 \\
138 & 100
\end{tabular}

TABLE 1V

Profile of Respondents as to Building Monthly Payment for Building for Business Purposes

Item

$$
\text { Manufacturer }
$$$$
\text { Dealer }
$$

Overall

Monthly Payment

Php5,000 - Php6,999

Php7,000 - Php8,999

Php9,000 - Php10,999

Php11,000 - Php12,999

More than Php13,000

No Response

Frequency Percentage

$\begin{array}{ll}28 & 68.29 \\ 0 & 0 \\ 0 & 0 \\ 0 & 0 \\ 2 & 4.88 \\ 11 & 26.83 \\ 41 & 100\end{array}$

Percentage

47.72
4.12
5.15
8.25
17.53
17.53

47.72

5.15

17.53

100
Frequency Percentage

$\begin{array}{ll}74 & 53.62 \\ 4 & 2.90 \\ 5 & 3.62 \\ 8 & 5.80 \\ 19 & 13.77 \\ 28 & 20.29 \\ 138 & 100\end{array}$

TABLE V

Profile of Respondents as to the Beginning Month of Manufacturing and Distribution of Pyrotechnics Products Item Manufacturer Dealer

Overall

Month of Production/Distribution

$\begin{array}{ll}\text { Frequency } & \text { Percentage } \\ 11 & 26.83 \\ 5 & 12.20 \\ 3 & 7.32 \\ 2 & 4.88 \\ 2 & 4.88 \\ 1 & 2.44 \\ 12 & 29.27 \\ 4 & 9.76 \\ 1 & 2.44 \\ 0 & 0 \\ 0 & 0 \\ 41 & 100\end{array}$

$\begin{array}{ll}\text { Frequency } & \text { Percentage } \\ & \\ 2 & 2.06 \\ 0 & 0 \\ 0 & 0 \\ 9 & 9.28 \\ 0 & 0 \\ 2 & 2.06 \\ 20 & 20.62 \\ 31 & 31.96 \\ 18 & 18.56 \\ 8 & 8.25 \\ 7 & 7.22 \\ 97 & 100\end{array}$

$\begin{array}{ll}13 & 9.42 \\ 5 & 3.62 \\ 3 & 2.17 \\ 11 & 7.97 \\ 2 & 1.45 \\ 3 & 2.17 \\ 32 & 23.19 \\ 35 & 25.36 \\ 19 & 13.77 \\ 8 & 5.80 \\ 7 & 5.07 \\ 138 & 100\end{array}$

TABLE V1

Profile of Respondents as to Peak Season Months for Manufacturing and Selling Distributing Pyrotechnics Products Item Manufacturer

Dealer

Overall

Peak Season Month

August

September

September

November

December

No Respons

Total

Copyright to IARJSET
Frequency Percentage

0

2.44

2.44
0

97.55

100

DOI 10.17148/IARJSET.2015.2102
Frequency Percentage

$\begin{array}{lll}1.03 & 1 & 0.72\end{array}$

1.03

0

69.07

6.19

100

0.72

0.72

15.94

77.54

4.35

100 


\section{TABLE V11}

Profile of Respondents as to Profit Earned by Pyrotechnics Manufacturers and Dealers

Item

Manufacturer

Frequency Percentage

Profit

Php100,000 - Php299,999

Php300,000 - Php499,999

Php500,000 - Php699,999

Php700,000 - Php999,999

Php 1,000,000 - Php2,999,999

Php3,000,000 and above

No Response

Total

$\begin{array}{ll}36 & 87.80 \\ 1 & 2.44 \\ 0 & 0 \\ 0 & 0 \\ 0 & 0 \\ 0 & 0 \\ 4 & 9.76 \\ 41 & 100\end{array}$

Dealer

Overall

Frequency Percentage

Management Practices of the Respondent Pyrotechnics Manufacturers and Dealers in Terms of:

TABLE V111

Management Practices on Production as to the Method of Obtaining Pyrotechnic Materials from Suppliers

Method

Cash/COD

Installment

On credit

Consignments
Frequency Percentage

92.68
0
58.54
7.32

Frequency Percentage

73
21
38
28

75.26
21.65

39.18

28.87

Overall

TABLE 1X

Management Practices on Dealership as to Terms of Sales and Deliveries

$$
\text { Item }
$$
Manufacturer Dealer

Terms of Sales and Deliveries Frequency Percentage Frequency Percentage

\section{Cash/COD \\ Installment \\ On credit}

Consignments

$\begin{array}{ll}38 & 92.68 \\ 1 & 2.44 \\ 23 & 56.10 \\ 7 & 17.07\end{array}$

$\begin{array}{ll}91 & 93.81 \\ 14 & 14.43 \\ 20 & 20.62 \\ 13 & 13.40\end{array}$

TABLE X

Management Practices on Dealership in Terms of Sales Increase

Item

Process Used

Fireworks products are posted in the internet Promotion by word of mouth

Discounts are given to customers

Fireworks products have better quality

\section{Manufacturer} Frequency Percentage

$\begin{array}{ll}1 & 2.44 \\ 39 & 95.12 \\ 4 & 9.76 \\ 22 & 53.66\end{array}$

Dealer

Frequency Percentage

$\begin{array}{ll}3 & 3.09 \\ 58 & 59.79\end{array}$

$\begin{array}{ll}38 & 39.18 \\ 77 & 79.38\end{array}$
Overall

Frequency Percentage

$129 \quad 93.48$

$15 \quad 10.87$

$43 \quad 31.16$

$20 \quad 14.49$

Common Problems Encountered by the Respondent Manufacturers and Dealers

TABLE X1

Problems with Greatest Impact in the Pyrotechnic Business

Item

Problems with Greatest Impact

Production cost

Higher insurance premiums

Various overhead expenses

Government safety regulations

Invasion of cheap imported products 3
Manufacturer

Frequency Percentage

$\begin{array}{ll}29 & 70.73 \\ 0 & 0 \\ 2.44 & \\ 1 & 2.44 \\ 75.61 & \end{array}$

\section{Frequency Percentage}

$48 \quad 49.48$

$4 \quad 4.12$

20.62

18

18.56

57

Overall

Frequency Percentage

$\begin{array}{ll}4 & 2.90 \\ 97 & 70.29 \\ 42 & 30.43 \\ 99 & 71.74\end{array}$

30.43

TABLE X11

Common Problems of Pyrotechnic Manufacturers and Dealers in the Area of Marketing (Combined Result) Common Problems in Marketing

Frequency

6
84
1
95
28
5

TABLE X111

Cost increases on supplies

Lack of information

Strong competition

Seasonality of the products

None

Common Problems of Pyrotechnic Manufacturers and Dealers in the Area of Finance (Combined Result)

Common Problems in Finance

Frequency

Percentage

Inaccessibility to credit

Short of cash for the initial capital

Short of cash for operating expenses

Overall

Frequency Percentage

$19 \quad 13.77$ 
Extent of Implementation of RA 7183 by the Two Groups of Respondents

TABLE X1V

Extent of Implementation of RA 7183 by the Manufacturer and Safety Policy Authority Respondents in Relation to Licensing Safety Policy Authorities

Interpretation

$$
\text { Mean }
$$

Verbal Interpretation

1.Register the business to SEC if the business is a corporation

$$
\text { 2. Register the business to DTI if the business is a single proprietorship }
$$

3 . Secure business permit duly issued by the municipal mayor/treasurer

of the place

4. Secure clearances of the manager from a) chief of police, PNP b) from

\subsection{0}

the court c) certificate of good conduct from the mayor of the city or municipality

5. The detail and location plan of the warehouse and manufacturing

complex is duly noted by the barangay chairman, and the chief of the local

fire station (mixing station, grinding station, packing station, pagmimitsa,

loading station)

6. The manufacturing compex is centifed that is is located in a designed

Area by the city/municipal engineer, barangay chairman, chief of the loca

fire station and by the mayor

\begin{tabular}{|c|c|c|c|}
\hline $\begin{array}{l}\text { N/A } \\
4.00\end{array}$ & Always & 2.63 & $\begin{array}{l}\text { More Often } \\
3.93\end{array}$ \\
\hline Always & & 3.93 & Always \\
\hline Always & & 3.63 & Always \\
\hline Always & & 3.91 & Always \\
\hline Always & & 3.91 & Always \\
\hline Always & & 3.61 & Always \\
\hline
\end{tabular}

MEAN

TABLE XV

Extent of Implementation of RA 7183 by the Manufacturer and Safety Policy Authority in Relation to Temporary Use Permit

Interpretation

$\begin{array}{ccc}\begin{array}{c}\text { Manufacturer } \\ \text { Mean }\end{array} & \text { Safety } & \text { Policy Authorities } \\ \text { Verbal Interpretation } & \text { Mean } \quad \text { Verbal }\end{array}$

1. Secure clearance from the Barangay Council for authority

to sell fireworks

2. The only activity within the premises is trading and

$\begin{array}{cccc}4.00 & \text { Always } & 3.86 & \text { Always } \\ 4.00 & \text { Always } & 3.55 & \text { Always } \\ & & & \\ 3.97 & \text { Always } & 3.45 & \text { Always } \\ 3.82 & \text { Always } & 3.24 & \text { Always } \\ 3.50 & \text { Always } & 3.43 & \text { Always } \\ 3.97 & \text { Always } & 3.60 & \text { Always } \\ & & & \\ 3.95 & \text { Always } & 3.68 & \text { Always } \\ 3.76 & \text { Always } & 3.29 & \text { Always } \\ 3.87 & \text { Always } & 3.51 & \text { Always }\end{array}$

selling of fireworks

3. The location of the store is in accordance with the

specifications of the authority

4. Expansion, alteration, improvement of the store is

not introduced without prior clearance from the authority

5 . My stores displays fireworks/finished products limited

to $50 \mathrm{kgs}$. Only

6 . The store provides a red painted drum filled with 50

gallons

of water labeled with "For Fire Use Only" and the name

of the store.

7. The store has an approved type of portable fire

extinguisher stationed inside the store.

8. A six inches letter size signage with "No Testing

$\&$ No smoking is posted in front of the store

MEAN

Extent of Implementation of RA 7183 by the Manufacturer and Safety Policy Authority Respondents in Relation to the Location of the Manufacturing Complex Manufacturer Safety Policy Authorities

Interpretation

$\begin{array}{llll}\text { 1. The manufacturing is } 300 \text { meters away from the nearest residential unit } & 3.74 & \text { Always } & 3.31\end{array}$

. The manufacturing complex: has an adequate ventilation, has no

concrete floor, is leak proof, has a fire extinguisher

3. The ware house is 50 meters away from any processing statio

4. The processing stations have the following distance from each other:

mixing -50 meters, grinding - 40 meters, packaging -40 metrs,

magmimitsa -20 meters, loading -20 meters

MEAN

3.87

Always

$3.62 \quad$ Always

$3.12 \quad$ Always

$3.80 \quad$ Always

$3.22 \quad$ Always

TABLE XV11

\begin{tabular}{|c|c|c|c|c|}
\hline \multicolumn{5}{|c|}{ to the sarety Guidennes wuring the processing or pyrotecnnic products } \\
\hline 1 & Manufacturer & Safety & Policy A & orities \\
\hline & Mean & Verbal Interpretation & Mean & Verbal \\
\hline \multicolumn{5}{|l|}{ Interpretation } \\
\hline 1. The workers have a minimum protective apparel & 1.75 & Rarely & 2.85 & More Often \\
\hline $\begin{array}{l}\text { 2. The workers are oriented about the hazards and corresponding } \\
\text { precautions of the chemicals he would be using }\end{array}$ & 3.68 & Always & 3.10 & Always \\
\hline $\begin{array}{l}\text { 3. The manufacturers inform the workers that the chemicals to be used } \\
\text { for processing shall be limited to the smallest quantity necessary for safe, } \\
\text { economical and efficient operations }\end{array}$ & 4.00 & Always & 3.40 & Always \\
\hline $\begin{array}{l}\text { 4. The workers mix the chemicals in a non-metallic containers; glass } \\
\text { should not also be used. }\end{array}$ & 3.85 & Always & 3.31 & Always \\
\hline 5. The workers keep the chemicals closed and covered in a containers & 4.00 & Always & 3.43 & Always \\
\hline at all times except during processing & & & & \\
\hline $\begin{array}{l}\text { 6. The workers use separate tools, scale pans, sieves for weighing the } \\
\text { chemicals }\end{array}$ & 3.87 & Always & 3.52 & Always \\
\hline $\begin{array}{l}\text { 7. The date when the chemicals was received and the date the container } \\
\text { is opened is clearly marked on all containers }\end{array}$ & 2.87 & More Often & 3.26 & Always \\
\hline $\begin{array}{l}\text { 8. The workers wash their hands and body thoroughly after a day's } \\
\text { exposure to chemicals and wash hand and face thoroughly before meals }\end{array}$ & 3.97 & Always & 3.24 & More Often \\
\hline MEAN & 3.50 & Always & 3.26 & Always \\
\hline
\end{tabular}

Extent of Implementation of RA 7183 by the Manufacturer and Safety Policy Authority Respondents in Relation to the Safety Guidelines During the Processing of Pyrotechnic Products 
TABLE XV111

Extent of Implementation of RA 7183 by the Dealer and Safety Policy Authority Respondents in Relation to Safety Measures to Prevent Fire and Damage to Properties, Injuries and Casualty Manufacturer

Interpretation

1. No Smoking within 10 meter radius perimeter of the fireworks store

2. No testing of any fireworks items within a 300 meter radius perimeter of the fireworks store

3. Putting signboard/notice measuring 18 inches wide $\mathrm{x} 24$ inches high, with written phrases "no smoking, no testing" in front of the store. The letters must be 6 inches high with a width of 1 inch.

4. Production of fireworks inside the store or near the store is prohibited

5. Stockpiling of fireworks inside the store is prohibited

6. Employment of minors is prohibited

7. Cooking inside the store is prohibited

8. Selling/peddling of any item using fire or flame in front of the store is prohibited

9. Drinking of any intoxicating drinks is prohibited within a 10 meter radius perimeter of the store

10. Putting of fire extinguisher inside the store is required

11. Putting of water filled red drum water container in front of the store with phrases "For Fire Use Only"

12. Fireworks items must be in a safe place like "estante". Placing

Fireworks items on the table outside of the store is prohibited.

13. Fireworks which are easy to explode such as bombshell must be Placed inside the box.

14. Putting the name of the manufacturer and the address in boxes or wrapper of fireworks is required

15. Putting of emergency light

16. The store is separated from other stores by a firewall with a fire

resistance of not less than two hours

MEAN

$\begin{array}{llll}\text { Mean } & \begin{array}{c}\text { Manufacturer } \\ \text { Verbal Interpretation }\end{array} & \text { Safety Policy Authorities } \\ & & 3.63 & \text { Always } \\ 3.97 & \text { Always } & 3.88 & \text { Always } \\ 3.95 & \text { Always } & 3.73 & \text { Always } \\ 3.96 & & & \\ & \text { Always } & 3.55 & \text { Always } \\ 3.88 & \text { Always } & 3.39 & \text { Always } \\ 3.81 & \text { Always } & 3.37 & \text { Always } \\ 3.86 & \text { Always } & 3.59 & \text { Always } \\ 3.93 & \text { Always } & 3.71 & \text { Always } \\ 3.95 & \text { Always } & 3.59 & \text { Always } \\ 3.93 & \text { Always } & 3.98 & \text { Always } \\ 4.00 & \text { Always } & 3.95 & \text { Always } \\ 3.94 & \text { Always } & 3.71 & \text { Always } \\ 3.93 & \text { Always } & 3.81 & \text { Always } \\ 3.99 & \text { Always } & 3.76 & \text { Always } \\ 3.90 & \text { Always } & 3.67 & \text { Always } \\ 3.78 & \text { Always } & 3.70 & \text { Always } \\ 3.94 & \text { Always } & 3.68 & \text { Always } \\ 3.92 & \text { Always } & & \end{array}$

Extent of Implementation of RA 7183 by the Manufacturer and Dealer Respondents in Relation to Licensing

Interpretation

1. I register the business to SEC if partnership or corporation

2. I register the business to DTI if the business is a single proprietorship

3. I secure business permit duly issued by the municipal mayor/treasure

$r$ of the place

4. I secure clearances of the manager from a) chief of police, PNP b)

from the court c) certificate of good conduct from the mayor of the city or municipality

5. The detail and location plan of my warehouse and manufacturing

5. The detail and location plan of my warehouse and manufacturing
Complex is duly noted by the barangay chairman, and the chief of the

local fire station (mixing station, grinding station, packing station,

pagmimitsa, loading station)

6. My manufacturing complex is certified that it is located in a designated area by the city/municipal engineer, barangay chairman, chief of the local fire station and by the mayor

MEAN

TABLE XX

Manufacturer
Mean $\quad$ Verbal Interpretation

Safety Policy Authorities

Mean Verbal

-- N/A

$4.00 \quad$ Always

$4.00 \quad$ Always

$3.97 \quad$ Always

3.66 Always

3.94 Always

4.00 Always

$3.99 \quad$ Always

$4.00 \quad$ Always

$3.98 \quad$ Always

$3.95 \quad$ Always

N/A

$3.98 \quad$ Always

Extent of Implementation of RA 7183 by the Manufacturer and Dealer Respondents in Relation to Temporary Use Permit

Manufacturer
Mean $\quad$ Verbal Interpretation

Safety Policy Authorities

Interpretation

Mean

Verbal

Always
2. The only activity within the premises is trading and selling of
fireworks
3. The location of the store is in accordance with the specifications
of the authority
4. Expansion, alteration, improvement of the store is not introduced
without prior clearance from the authority
5. My stores displays fireworks/finished products limited to $50 \mathrm{kgs}$. Only
6. The store provides a red painted drum filled with 50 gallons of water
labeled with "For Fire Use Only" and the name of the store.
7. The store has an approved type of portable fire extinguisher stationed
inside the store.
8 . A six inches letter size signage with "No Testing \& No smoking is
posted in front of the store
9. The firework storage is located at a safe distance away from the
location of the store and/or nearest residential/commercial areas

$\begin{array}{ll} & 4.00 \quad \text { Always } \\ 4.00 & \text { Always } \\ 3.97 & \text { Always } \\ 3.82 & \text { Always } \\ 3.50 & \text { Always } \\ 3.97 & \text { Always } \\ 3.95 & \text { Always } \\ 3.76 & \text { Always } \\ -- & \text { N/A } \\ 3.87 & \text { Always }\end{array}$

$\begin{array}{ll} & 3.98 \\ 3.92 & \text { Always } \\ 3.94 & \text { Always } \\ 3.71 & \text { Always } \\ 2.71 & \text { More Often } \\ 3.97 & \text { Always } \\ 4.00 & \text { Always } \\ 4.00 & \text { Always } \\ 3.91 & \text { Always } \\ 3.79 & \text { Always }\end{array}$

Significant Difference in the Extent of Implementation of Safety Measures by the Two Groups of Respondents TABLE XX1

Significant Difference in the Extent of Implementation by Dealer and Safety Policy Authority

\begin{tabular}{|c|c|c|c|c|c|c|}
\hline & & ats ir & ion & nsing & & \\
\hline Group & Mean & $\mathbf{T}$ & DF & Sig. (2 tailed) & Decision & Remarks \\
\hline 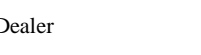 & 3.91 & 606 & 132 & 000 & Reiect $\mathrm{Ho}$ & Sionificant \\
\hline
\end{tabular}




\section{TABLE XX11}

Significant Difference in the Extent of Implementation by the Dealer and Safety Policy Authority

\begin{tabular}{llccccc} 
Group & \multicolumn{2}{c}{ Respondents in Relation to Temporary Use of Permit } & Decision & Remarks \\
Mean & 3.79 & T & DF & Sig.(2 tailed) & Decignificant \\
Dealer & & & 4.754 & 133 & 0.00 & Reject Ho
\end{tabular}

TABLE XX111

Significant Difference Extent of Implementation by the Dealer and Safety Policy Authority Respondents in Relation to Safety Practices to Prevent Fire and Damage to Properties, Injuries and Casualty

$\begin{array}{lllllll}\text { Group } & \text { Mean } & \text { T } & \text { DF } & \text { Sig.(2 tailed) } & \text { Decision } & \text { Remarks } \\ \text { Dealer } & & 3.92 & 3.266 & 135 & 0.00 & \text { Reject Ho } \\ \text { Safety Policy Authority } & 3.66 & & & & \end{array}$

\section{TABLE XX1V}

Significant Difference in the Extent of Implementation by the Manufacturer and Dealer

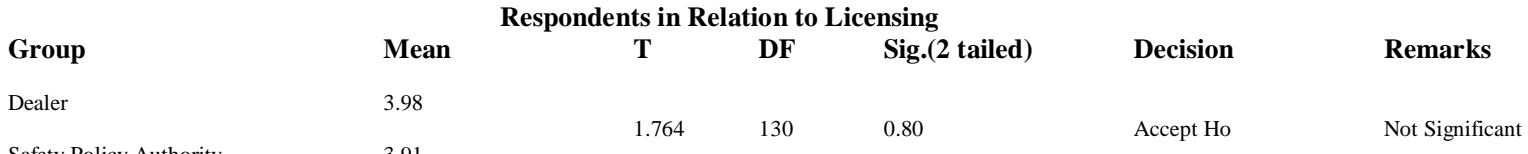

Safety Policy Authority 3.91

TABLE XXV

Significant Difference in the Extent of Implementation by the Manufacturer and Dealer

\begin{tabular}{llccccc} 
Group & \multicolumn{4}{c}{ Respondents in Relation to Temporary Use Permit } & Decision & Remarks \\
Mean & T & DF & Sig.(2 tailed) & Decept Ho \\
Dealer & 3.87 & -0.558 & 131 & 0.57 & Accet Significant \\
Safety Policy Authority & 3.79 & & &
\end{tabular}

\section{BIOGRAPHY}

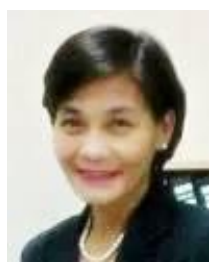

Dr. Felicidad A. Dy Kam completed her degree in Liberal Arts and Commerce major in Economics and Management from Ateneo de Naga University. She took her Master in Business Administration and Doctor in Business Administration from Polytechnic University of the Philippines. She has taught in various universities in the Philippines. She has also an international exposure abroad as visiting professor for 3 months in one of the universities in China and for two years as visiting professor in South Korea. Currently, she is working as an Assistant Professor at AMA International University-Bahrain where she handles Management and Economics subjects. 